\title{
REVOLUSI MENTAL DAN REVOLUSI ETOS KERJA: UPAYA MEMBANGUN BANGSA INDONESIA YANG LEBIH BERMARTABAT
}

\author{
Desmita \\ Program Studi Bimbingan Konseling, Jurusan Tarbiyah, STAIN Batusangkar \\ Korespondensi: Jl. Sudirman No. 137, Kuburajo, Lima Kaum, Batusangkar, Sumatera Barat \\ e-mail: desmita.stain@gmail.com
}

\begin{abstract}
Mental revolution is a national movement and political jargon initiated by the Indonesian government nowadays. By using this jargon, it is expected that Indonesian people could achieve their dignity to be an independent, nobility, justice, and prosperous country. The mental revolution should be begun with job ethos - a mental attitude to see a job meaningfully. Job ethos is not seen as an effort to get salaries only. It is, however, an effort to do something meaningfully. Job ethos will affect employee such as farmers, workers, merchants, and civil servant to do their jobs successfully and meaningfully.
\end{abstract}

Kata kunci: revolusi, mental, etos kerja,

\section{PENDAHULUAN}

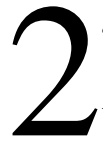

4 tahun yang lalu, tepatnya tanggal 14 sampai 16 Januari 1991, secara berturut-turut Harian Kompas memuat tulisan Koentjaraningrat, Guru Besar Antropologi Universitas Indonesia, tentang kondisi sosial budaya bangsa Indonesia saat itu. Dalam bagian pertama tulisannya yang diberi judul "Kendala Sosial Budaya dalam Pengamalan Pancasila", Koentjaraningrat (1991) menyebutkan beberapa kendala sosial budaya yang menyebabkan bangsa Indonesia tidak kunjung tampil sebagai negara maju yang mampu tegak sama tinggi dan duduk sama rendah dengan negara-negara maju lainnya. Kendala tersebut di antaranya, pertama, masih rendahnya tingkat pendidikan orang Indonesia dan kurang "beradab".

Rendahnya tingkat pendidikan di kalangan orang-orang muda membuat mereka "tanggung", dalam arti mereka tidak lagi mau dan mampu bekerja de- ngan tangan, namun tidak pula terampil melakukan pekerjaan administratif yang paling sederhana sekalipun. Sementara itu, kurang "beradab" dimaksudkan kurang dalam hal sopan santun, tenggang rasa dan kemampuan menahan diri, serta tidak hemat, kurang memiliki rasa tanggung jawab, kurang taat pada prinsip, peraturan dan hukum, kurang bersikap demokratis dan kurang berdisiplin.

Kedua, orang Indonesia masih bermentalitas pegawai dan masih berorientasi pada sikap "feodal", dan karenanya mereka belum sepenuhnya menjunjung tinggi pranata demokrasi. Dengan mentalitas pegawai yang masih melekat pada sebagian besar orang Indonesia maka mereka sangat rendah dalam keberanian mengambil resiko, tidak dinamis, kurang kreatif dan inovatif. Sementara itu, dengan mentalitas feodal, terlihat betapa kebanyakan orang Indonesia sangat mengagungkan kekuasaan dan pangkat tinggi, bahkan sering kali 
dalam arti negatif, yaitu sikap sombong yang diakibatkan oleh kekuasaan dan pangkat tinggi yang dimilikinya, dan akhir-akhir ini bahkan juga oleh kekayaan, sikap menjilat, dan seterusnya (Koentjaraningrat, 1991). Lebih jauh Koentjaraningrat dalam bagian ketiga tulisannya di Harian Kompas tanggal 16 Januari 1991 dengan judul "Jiwa Feodal, Mentalitas Pegawai, dan Disiplin Nasional" menjelaskan bahwa mentalitas yang mengagungkan kekuasaan dan pangkat tinggi tetap bertahan dalam jiwa bangsa Indonesia pada umumnya, karena melalui proses sosialisasinya mentalitas tersebut sudah tertanam dalam diri seseorang sejak sangat dini (Koentjaraningrat, 1991).

Tulisan Koentjaraningrat di atas, meskipun ditulis 24 tahun yang lalu dan jauh sebelum tumbangnya dominasi kekuasaan Orde Baru dan bangkitnya Era Reformasi, agaknya masih relevan untuk dijadikan rujukan dalam mencermati realitas bangsa Indonesia saat ini. Betapa tidak, Masalah mentalitas ternyata masih menjadi masalah akut yang tak kunjung terselesaikan oleh bangsa ini. Ironis memang, sudah 70 tahun bangsa Indonesia mengalami masa kemerdekaan, namun permasalahan mentalitas masih saja menjadi penyakit menahun yang selalu menggerogoti sendi-sendi kehidupan berbangsa dan bernegara. Sedemikian parahnya penyakit mentalitas yang dialami bangsa ini mengakibatkan Indonesia tidak kunjung mampu bangkit dan keluar dari berbagai krisis kehidupan yang sudah berlangsung hampir 20 tahun.

Sebagai diketahui sejak 1997, di samping dilanda krisis ekonomi dan politik, bangsa Indonesia juga mengalami krisis nilai budaya. Krisis nilai budaya menjadikan bangsa Indonesia kelihatan bodoh, tidak percaya diri dan mudah diperdaya oleh bangsa lain. Dampak krisis nilai budaya juga terlihat nyata dari konflik-konflik komunal yang semakin meluas, mulai dari perebutan wilayah atau tanah garapan, konflik antar-agama, konflik antar-golongan, konflik antarsuku atau etnis, konflik antar-elit partai, sampai pada konflik yang bermotifkan dendam. Berbagai konflik yang terjadi di masyarakat tersebut tidak saja telah menyebabkan kondisi negeri ini menjadi kacau balau dan menimbulkan kengerian pada anggota masyarakat, melainkan juga telah mengancam keutuhan Negara Kesatuan Republik Indonesia (Desmita, 2004)).

Krisis nilai budaya juga menyebabkan hilangnya saling percaya (trust) dan rasa empati atau tepa selira. Menurut Institute of Future Studies for Development di Bangkok (Asia Week, December 1998), saling percaya adalah kunci untuk menyelesaikan krisis. Sementara itu empati adalah jaringan rasa sebagai basis kebudayaan yang memungkinkan terbangunnya kerukunan dan dialog sosial di setiap masyarakat. Dengan saling percaya dan membangun empati masyarakat akan dapat saling tolong menolong dan bekerja sama. (Kompas, 1999).

Yudi Latif (2011), seorang tokoh muda intelektual muslim, juga merefleksikan kesadaran dan keprihatinan bahwa krisis yang mendera kehidupan kebangsaan saat ini begitu luas cakupannya dan dalam penetrasinya. Dia menggambarkan "Kehidupan kota (polis) yang semestinya menjadi basis keberadaban (madani) terjerumus ke dalam apa yang disebut Machiavelli sebagai "kota korup" (citta corrottisima) atau apa yang disebut Al Farabi sebagai "kota jahiliyah" (almudun al-jahiliyyah). Di republik korup dan jahil persahabatan madani sejati hancur. Tiap warga berlomba mengkhianati bangsa dan sesamanya, rasa saling percaya memudar, hukum dan institusi lumpuh sehingga tidak mampu meredam penyalahgunaan kekuasaan (korupsi), ketamakan dan has- 
rat meraih kehormatan rendah merajalela, kebaikan dimusuhi, kejahatan diagungkan. Gejala money politics dan fenomena-fenomena turunannya adalah bagian dari krisis yang perlu segera dieliminir dalam kehidupan berbangsa dan bernegara.

Mencermati realitas bangsa Indonesia yang telah sampai pada kondisi yang gawat darurat tersebut maka muncul keinginan untuk melakukan apa yang dikenal dengan "revolusi mental". Revolusi mental dianggap sebuah alternatif pemecahan masalah berbagai krisis yang mendera bangsa ini. Melalui revolusi mental bangsa Indonesia diyakini akan dapat menemukan kembali kemanusiaannya yang hilang (the lost humanity) dan titik awal (starting point) untuk membangun sebuah masyarakat atau peradaban baru yang lebih baik.

Dalam tulisan ini penulis ingin menguraikan tentang revolusi etos kerja sebagai bagian penting yang perlu mendapat perhatian dalam pelaksanaan program revolusi mental yang tengah dijalankan oleh pemerintah dewasa ini. Hal ini didasarkan pada realitas bangsa Indonesia, sebagaimana disinggung oleh Koentjaraningrat di atas, masih terbelenggu oleh mentalitas pegawai yang memiliki etos kerja yang rendah, tidak kreatif, tidak inovatif, bekerja seadanya, malas, dan bahkan masih menganut prinsip "kerja sedikit, hasil (uang) banyak".

\section{Revolusi Mental: Pemahaman Kon- septual}

Revolusi mental sebenarnya bukanlah sebuah istilah baru. Istilah revolusi mental telah banyak digunakan dalam sejarah pemikiran, manajemen, sejarah politik dan bahkan sejarah musik. Penggunaan itu terjadi baik di dunia Barat maupun Timur, baik oleh pemikir Islam, Kristiani, Hinduisme maupun (Zen) Buddhisme. Bahkan Bung Karno sendiri pernah menggunakan istilah ini dalam pidato 17 Agustus 1962. Istilah revolusi mental belakangan digemakan dan dihidupkan kembali oleh Jokowi dan dijadikan sebagai jargon politik dalam kompanye pemilihan presiden tahun 2014 silam.

Secara etimologi, istilah "revolusi mental" terdiri dari dua kata yang berlainan arti, "revolusi" dan "mental". Untuk memudahkan pemahaman, sebaiknya dijelaskan terlebih dahulu pengertian masing-masing kata tersebut kemudian baru dijelaskan pengertian secara keseluruhan.

\section{Revolusi}

Kata "revolusi" berasal dari bahasa Inggris yang berarti: "putaran", "balingan", "perkisaran", "perubahan", dan "pusingan" (J.M. Echols \& Hassan Shadily, 2010). Dalam Kamus Besar Bahasa Indonesia (1992), kata revolusi diartikan sebagai (1) perubahan ketatanegaraan (pemerintahan atau keadaan sosial) yang dilakukan dengan kekerasan (seperti dengan perlawanan bersenjata); (2) perubahan yang cukup mendasar dalam suatu bidang; (3) peredaran bumi dan planet-planet lain dalam mengelilingi matahari.

Menurut Yudi Latif (2014) secara denotatif, revolusi berarti "kembali lagi" atau "berulang kembali"; ibarat musim yang berganti secara siklikal untuk kembali ke musim semula. Berdasarkan pengertian ini, maka dalam sains istilah revolusi mengimplikasikan suatu ketetapan (konstanta) dalam perubahan; pengulangan secara terus-menerus yang menjadikan akhir sekaligus awal.

Istilah "revolusi" pada awalnya merupakan sebuah istilah dalam sains astronomi yang digunakan untuk menggambarkan siklus pergerakan (movement) benda-benda langit (Leahey, 1992). Pada tahun 1543, Nicholaus Copernicus mempublikasikan buku De Revolutionibus Orbium Coelestium, 
yang sering dinisbatkan sebagai penanda revolusi paradigmatik dalam sains yang mengubah keyakinan tentang pusat alam semesta dari geosentrisme (berpusat di bumi) menuju heliosentrisme (berpusat di matahari) perubahan mendasar dalam keyakinan ilmiah ini kemudian dikenal sebagai revolusi Copernican.

Istilah revolusi dalam kaitan ini bergeser dari pengertian sebelumnya menjadi apa yang didefinisikan oleh Thomas Kuhn sebagai "perubahan dalam susunan keyakinan saintifik atau dalam paradigma". Di sini pengertian revolusi tidak lagi menekankan aspek kesinambungan dalam daur ulang (unbroken continuity), melainkan justru sebagai keterputusan dalam kesinambungan (break in contiunity). Sejak itu, istilah revolusi diartikan sebagai suatu perubahan struktur mental dan keyakinan karena introduksi gagasan dan tatanan baru yang membedakan dirinya dari gagasan dan tatanan masa lalu (Cohen, 1985).

Pengertian revolusi seperti itulah yang kemudian diadopsi dan digunakan dalam wacana dan gerakan sosial-politik. Penggunaan istilah revolusi dalam bidang politik memperoleh populeritasnya menyusul Revolusi Amerika (1776) dan terlebih setelah Revolusi Francis (1789). Seperti halnya revolusi dalam sains, pengertian revolusi dalam politik pun pada mulanya mengandung konotasi yang ramah, hingga Revolusi Francis berubah jadi ekstrem dalam bentuk teror yang menakutkan. Konotasi menakutkan dari istilah revolusi tersebut menguat menyusul publikasi The Communist Manifesto pertengahan abad ke-19, revolusi 1848 dan gerakan komunis internasional dengan agenda revolusi berskala dunia yang mengandung ekspresi kekerasan terkait dengan perubahan cepat (Yudi Latif, 2014).

Kerena itu, belakangan revolusi cenderung digunakan untuk menggambar- kan sebuah perubahan fundamental dalam pemerintahan atau konstitusi politik sebuah negara, terutama yang terjadi karena sebab-sebab internal dan lewat suatu pergolakan bersenjata, dan rusuh. Revolusi dalam pengertian ini misalnya terlihat dari rumusan yang diberikan Anthony Reid (1981), yaitu revolusi adalah "restrukturisasi fundamental dari suatu sistem politik dengan kekerasan dalam jangka waktu yang relatif singkat".

Tetapi, sejumlah ilmuwan tidak setuju dengan kata "kekerasan" yang terdapat dalam definisi revolusi tersebut. Sebab, kekerasan dan perubahan cepat bukanlah elemen esensial dari suatu revolusi. Revolusi tidak mesti dengan jalan kekerasan. Peter L. Berger misalnya menunjukkan suatu revolusi nirkekerasan. Demikian juga dengan Roeslan Abdulgani (1981), tidak setuju menghubungkan kata "kekerasan" dengan "revolusi", sebab adakalanya revolusi atau perubahan cepat itu berlangsung tanpa pertumpahan darah, meskipun seringkali pertumpahan darah itu tak terhindarkan di dalamnya. Lebih jauh Roeslan Abdulgani (1981) menjelaskan bahwa revolusi adalah perubahan yang mendadak dan berlangsung cepat, atau di dalamnya terjadi lompatan-lompatan. Selain berlangsung cepat, perubahan dalam revolusi juga bersifat fundamental dan secara kualitas.

Sudjarwo (1981) juga tidak menyinggung kata kekerasan ketika menjelaskan konsep revolusi. Sudjarwo memahami revolusi sebagai alternatif terjauh dari gagasan atau ide untuk menyelesaikan masalah yang berkembang dalam masyarakat. Gagasan ini selanjutnya akan menimbulkan sejumlah tindakan yang dipandang revolusioner. Sebagai akibat adanya gagasan dan tindakan revolusioner, terjadilah revolusi. Jadi, revolusi menurut Sudjarwo lebih merupakan istilah yang mengandung 
pengertian alat, cara bertindak dan hasil tindakan itu sendiri.

Mengutip Hannah Arendt, Yudi Latif mengingatkan bahwa konsep modern tentang revolusi terkait dengan pengertian bahwa jalannya sejarah seketika memulai hal baru. Revolusi mengimplikasikan suatu kisah baru, kisah yang tidak pernah diketahui atau diceritakan sebelumnya. Revolusi menjadi jembatan yang menstransformasikan dunia lama menjadi dunia baru.

Singkatnya, sebagaimana dijelaskan oleh S.N. Eisendadt (1986), revolusi terkait dengan gagasan perubahan menyeluruh, pembaharuan dan diskontinuitas menyeluruh dan juga menganut asumsi bahwa revolusi erat hubungannya dengan transformasi sosial. Transformasi sosial di sini menurut Yudi Latif (2014) harus mengandung kebaruan dalam struktur mental dan keyakinan. Dengan kata lain, revolusi sejati meniscayakan perubahan mentalitas (pola pikir dan sikap kejiwaan) yang lebih kondusif bagi perbaikan kehidupan.

\section{Mental}

Secara etimologi, kata "mental" berasal dari bahasa Latin, mens atau mentis, yang berarti "roh", "sukma", "jiwa" atau "nyawa". Dalam Kamus Inggris Indonesia yang ditulis oleh John M. Echols dan Hassan Shadily (2010) mental diartikan (1) yang berhubungan dengan jiwa; (2) batin, rohaniah. Sedangkan kata "mentality" diartikan sebagai "daya otak" "kapasitan mental" atau mentalitas.

Berdasarkan pada pengertian secara etimologi di atas dapat dipahami bahwa kata mental merupakan sebuah istilah yang digunakan untuk menggambarkan struktur rohaniah, dimensi yang tidak terlihat yang membentuk kepribadian manusia atau substansi psikologis manusia yang menjadi esensi keberadaannya.
Sebagaimana dipahami bahwa manusia merupakan makhluk monodualis. Artinya, mikrokosmos manusia terdiri dari dua dimensi dasar, yaitu dimensi badan dan ruh, atau yang terlihat dan yang tak terlihat, atau materi dan immateri. Mental dalam hal ini termasuk dalam dimensi batin atau rohaniah, dimensi ruh atau jiwa, yang dalam psikologi Islam disebut al-nafs dan alruh. Unsur ruh atau jiwa manusia ini sangat misteri. Ia bersifat immateri karena berasal dari substansi immateri di alam gaib. Untuk lebih memudahkan pemahaman tentang dimensi rohaniah manusia ini ada baiknya dikutip penjelasan M. Dawam Rahardjo (1994), yaitu:

Terdapat perbedaan dalam penggunaan kata "ruh" dan "roh". Istilah ruh itu sering diartikan dengan jiwa atau semangat. Sedangkan kata roh diasosiasikan dengan nyawa, yang menyebabkan seseorang itu hidup. Kata roh juga dipergunakan untuk pengertian roh manusia di alam gaib atau akhirat. Pertanyaan yang paling sering muncul adalah, apakah perbedaan antara ruh dan roh dengan nyawa atau jiwa. Dalam bahasa Inggris, ruh atau roh diterjemahkan sebagai "spirit," sedangkan nyawa atau jiwa diterjemahkan dengan "soul". Mengacu kepada Alquran, spirit itu merupakan terjemahan Inggris dari kata "al-ruh”, sedangkan jiwa atau nyawa dari kata "al-nafs". Ruh yang kata padanan Inggrisnya adalah spirit, merupakan bagian yang non-individual dari jiwa (soul), yang disebut juga oleh berbagai filsuf sebagai intellect atau nous. Dalam bahasa Arabnya adalah al-'aql alfa'al, atau fa'il. Kebalikan dari spirit ini adalah soul atau psyche. Dalam bahasa Arabnya adalah al-nafs. Yang terakhir ini bersifat individual. Dengan demikian, maka spirit itu adalah 
gabungan dari jiwa yang sifatnya individual. Jika digambarkan secara matematis, maka ruh atau spirit adalah sebuah set, sedangkan al-nafs atau jiwa adalah sub-set. Jiwa yang bersifat individual itu berkesinambungan dengan wujud (being) itu sendiri yang disebut al- 'aql al-awwal.

Kutipan di atas memberikan pemahaman yang jelas tentang makna mental sebagai bagian dari unsur kejiwaan dan menjadi kekuatan terdahsyat dari makhluk manusia. Betapa tidak, di dalam dimensi rohaniah manusia yang disebut mental terkandung daya-daya jiwa yang menjadi modal dasar bagi manusia untuk lebih dari sekedar dapat bertahan hidup tetapi juga untuk membangun dan memakmurkan bumi sebagaimana yang diamanahkan Allah SWT.

Menurut Harun Nasution (1991), daya-daya jiwa yang dianugerahkan Allah kepada manusia tersebut secara garis besarnya dapat dibedakan atas dua yaitu daya berpikir yang disebut al-'aql dan berpusat di kepala serta daya merasa yang disebut al-qalb dan berpusat di jantung. Daya akal merupakan dimensi yang paling berharga dari manusia. Alquran sendiri memberikan penghargaan dan kedudukan yang tinggi kepada dimensi akal, meskipun secara eksplisit kata al-'aqlu (akal) sebagai kata benda tidak ditemukan dalam Alquran. Alquran hanya menyebutkan bentuk aktivitas akal, yang kesemuanya menunjukkan terhadap proses berpikir manusia. Ini menunjukkan bahwa akal bukanlah suatu substansi yang bereksistensi, melainkan aktivitas substansi tertentu.

Daya akal dipandang sebagai pembeda manusia dengan binatang. Dengan daya akal, manusia dapat menerima ilmu teoritis (al-nadhariyah) dan merekayasa pemikiran, sehingga dapat mewujudkan kebudayaan dan peradaban yang tinggi serta mengembangkan ilmu pengetahuan dan teknologi dalam rangka mencapai kesejahteraan dan kebahagiaan hidup. Kekuatan akal dapat mengantarkan manusia pada pemahaman mengenai hakikat-hakikat dan rahasia-rahasia alam. Bahkan, apabila kekuatan akal itu telah bersih dari pengaruh kekuatan materi, memungkinkan manusia dapat melihat apa yang tersembunyi dan mengungkapkan apa yang tidak diketahui, serta mampu menjangkau hakikat-hakikat transendental dan menangkap makna penting dari tanda-tanda Tuhan, yang dalam bahasa Al-Qur'an disebut hayah. Hal ini dimungkinkan, karena akal adalah ruh yang dianggap sebagai dimensi yang paling bercahaya dari manusia, yang paling dekat dengan Tuhan, karena akal tidak lain adalah cahaya-Nya sendiri yang ditempatkan di dalam jiwa manusia. Akal dalam hal ini berfungsi sebagai "belenggu" untuk melawan kebodohan, sedangkan jiwa adalah seperti hewan yang paling buruk. Jika ia tidak mempunyai akal, ia berkeliaran dalam kebingungan (Harun Nasution, 1991).

Jadi, orang yang mampu memfungsionalkan akalnya tidak mau bertindak bodoh, karena dengan akalnya itu ia akan melakukan suatu perbuatan dengan terlebih dahulu mempertimbangkan akibatnya, bukan atas dasar syahwat yang bersifat tergesa-gesa dan tanpa perhitungan. Berdasarkan pemahaman ini, maka $\mathrm{M}$. Quraisy Shihab (1996) mengartikan akal sebagai: a) Daya untuk memahami dan menggambarkan sesuatu (QS. Al-Ankabut: 43), b) Dorongan moral (QS. Al-An'am: 151), dan c) Daya untuk mengambil pelajaran serta hikmah. Daya ini menggabungkan kedua daya di atas, sehingga akal mengandung daya memahami, menganalisis, menyimpulkan, serta dorongan moral yang disertai dengan kematangan berpikir.

Di samping daya akal, manusia juga memiliki daya kalbu (qalb) atau hati, yakni daya ruhaniah manusia yang mempunyai 
kaitan erat dengan daya 'aql. Secara etimologi kata qalb berasal dari kata: qalab - yaqlibu - qalban, yang memiliki banyak arti di antaranya: "membalik, menukar, menjadikan, berpaling, berubah, berbalik-balik, pusat, sari, batin, hati, akal, dan sebagainya (Mahmud Yunus, 1989). Kata al-qalb ditemukan di dalam Alquran sebanyak 144 kali dengan pengertian yang bermacam-macam, di antaranya qalb sebagai wadah atau tempat iman dan hidayah, wadah ilmu dan ma'rifat, wadah keinginan dan putus asa, sedih, cinta, perasaan senang, bahagia dan sebagainya. Menurut Abdul Mujib (1999), qalb merupakan wadah dari pengajaran, perasaan (emosi), seperti emosi cinta dan kasih sayang, emosi takut, bimbang, ragu-ragu, keimanan, maksiat, dosa dan sebagainya. Dengan demikian, qalb memiliki dayadaya atau potensi, yaitu daya emosi yang menimbulkan daya rasa, seperti tenang (thuma'ninah), jinak atau sayang ('ulf), senang (ya'aba), santun dan penuh kasih sayang (ra'fa wa rahmat), tunduk dan bergetar (wajilat), mengikat (ribath), kasar (shalizh), takut (ru'b), dengki (ghill), berpaling (zaygh), panas (ghalith), sombong (hamiyat), kesal (isyma'azzat), dan lain-lain. Potensi kognisi yang menimbulkan daya cipta, seperti berpikir (' $a q l)$, memahami (figh), mengetahui ('ilm), memperhatikan $(d a b r)$, mengingat (zikr), dan melupakan (ghuff). Potensi konasi yang menimbulkan daya karsa, seperti dalam berusaha (kasb).

Daya akal dan daya qalbu sebenarnya merupakan dua potensi ruhaniah manusia yang tidak dapat dipisahkan. Sebaliknya, kedua daya tersebut saling berkaitan dan merupakan satu kesatuan dalam mewujudkan manusia menjadi makhluk Tuhan yang seutuhnya.

Dari uraian di atas dapat dipahami bahwa mental merupakan dimensi rohaniah manusia yang berkaitan dengan pikiran, mind, batin atau watak atau kejiwaan, yang akan membentuk karakteristik tingkah laku dan kepribadian seseorang. Karena itu, istilah revolusi mental cenderung didefinisikan sebagai perubahan fundamental dari cara berpikir manusia. Dalam hal ini, Agus Santoso (2014) misalnya, mendefinisikan revolusi mental sebagai suatu perubahan mendasar dan radikal dalam cara hidup, mulai dari cara berpikir dan memandang realitas; cara merasa, meyakini atau mempercayai; cara bertindak, sampai cara berwicara atau berwacana. Revolusi mental mengajak kita untuk menyadari dan mengubah sikap hidup yang tidak sekedar hanyut dalam arus kehidupan serta tidak menjalani hidup sekedar pasrah mengalir seperti air, sebab hidup ini sering melawan arus.

Menurut Agustinus Daniel (2014), mental revolution is a radical transformation from the old person, which is the source of the civilization crisis into a new person which return to live in true humanity. What will be changed in the Mental Revolution is the human quality, the character, the mental attitude, and the perspective on life.

Jadi, yang dimaksud dengan revolusi mental menurut Agustinus Daniel adalah suatu transformasi radikal dari pribadi yang menjadi sumber bencana dan krisis peradaban menjadi pribadi yang humanis. Perubahan ini meliputi perubahan kualitas kemanusiaan, karakter, sikap mental dan perspektif tentang kehidupan.

Menurut Teguh Hindarto (2014), revolusi mental" berkaitan dengan perubahan sikap, perilaku, cara berfikir, tindakan, etos agar tercipta Indonesia Baru yang lebih sejahtera secara ekonomi dengan diiringi keadaban mentalitas setiap warga negaranya. Apalah artinya kemajuan ekonomi namun mengalami kerusakkan mental sebagai bangsa? Mental korupsi, mental menyuap, 
mental menjilat, mental kolusi, mental suka menyalahkan kesalahan pada bangsa lain, mental diskriminatif, mental primordialistik, mental malas bekerja, mental fatalistik, mental hipokrit. Mental yang sehat berpengaruh terhadap perilaku berpolitik. Mental yang sehat berpengaruh terhadap kebijakan ekonomi. Mental yang sehat berpengaruh terhadap produktifitas pekerjaan.

Dari beberpa definisi di atas dapat dipahami bahwa revolusi mental dimaksudkan sebagai perubahan radikal dan mendasar atas mindset, pandangan hidup, dan jiwa yang melahirkan kesadaran etik dan moral. Kesadaran etik membawa bangsa pada perilaku yang memuliakan nilai, norma, dan hukum. Dengan kata lain, revolusi mental bermaksud bagaimana bangsa ini dibawa kepada perubahan mentalitas yang mencerahkan, dari yang buruk kepada yang baik sesuai etika dan moralitas dalam tata kehidupan masyarakat. Karena menyangkut mentalitas, ia berkaitan erat dengan budaya. Meminjam istilah Yudi Latif (2014), usaha revolusi mental harus menyasar aspek terpenting yang menentukan perilaku manusia, yakni karakter personal dan budaya (sistem nilai, sistem pengetahuan dan sistem perilaku sebagai pembentuk karakter kolektif). Dalam proyek transformasi budaya, perlu diidentifikasi mentalitas inti sebagai penggerak utama bagi kelahiran mentalitas-mentalitas turunannya.

Dalam konteks inilah Karlina Supelli (2014) memandang revolusi mental sebagai semacam strategi kebudayaan, yakni haluan umum yang berperan memberi arah bagaimana kebudayaan akan ditangani, supaya tercapai kemaslahatan hidup berbangsa. Untuk agenda revolusi mental, kebudayaan mesti dipahami bukan sekedar sebagai seni pertunjukkan, pameran, kesenian, tarian, lukisan, atau celoteh tentang moral dan kesadaran, melainkan sebagai corak/pola cara berpikir, cara merasa, dan cara bertindak yang terungkap dalam tindakan, praktik dan kebiasaan seharihari.

\section{Revolusi Mental dan Etos Kerja}

Mencermati uraian di atas dapat dimengerti bahwa sebenarnya sasaran yang hendak dibidik oleh revolusi mental pada dasarnya adalah transformasi etos, yaitu perubahan mendasar dalam mentalitas, cara berpikir, cara merasa dan cara mempercayai, yang kesemuanya menjelma dalam perilaku dan tindakan keseharian. Etos di sini menyangkut semua bidang kehidupan, mulai dari ekonomi, politik, sains-teknologi, seni, agama, dan seterusnya. Dengan transformasi etos akan membawa baik budaya ide (ilmu, pengetahuan) budaya ekspresi (seni dan nonseni) maupun budaya material. Karena itu menurut Jansen Sinamo (2014), revolusi mental yang menjadi visi dan misi pemerintahan sekarang ini harus diwujudkan secara masif dan holistik menjadi etos kerja nasional dalam segala bidang, terutama pendidikan, hukum, politik, birokrasiadministrasi, korporasi-korporasi, senibudaya, keamanan-ketahanan, serta sains-teknologi dan industri-ekonomi.

Etos adalah sebuah kata Yunani. Dalam ejaan Yunani, huruf "e" dalam kata "etos" dapat berupa epsilon (e pendek) dan dapat pula berupa eta (e panjang). Jika "e"-nya adalah epsilon, maka etos berarti "kebiasaan", "adat" atau "asal mula". Tetapi, jika "e"-nya adalah eta, maka etos berarti: (1) tempat tinggal, atau stasiun; (2) adat, kesusilaan, kebiasaan, watak, atau cara berbuat; dan (3) perhatian, atau keramahan hati (Wiratmo Soekito, 1978).

Para ahli filsafat mengartikan etos sebagai suatu karakter (dalam suatu pementasan drama) yang harus menjadi watak sang aktor. Sedangkan ahli sosiologi mengartikan etos sebagai sejumlah 
perangai budaya karakteristik yang memperbedakan dan memperlainkan suatu kelompok dengan kelompok lainnya (Wiratmo Soekito, 1978).

Menurut Wiratmo Soekito, (1978), etos adalah masalah tentang yang baik dan yang buruk, yang bajik dan yang jahat, yang benar (dalam arti adil) dan yang salah, dan seterusnya. Sementara itu Jansen Sinamo (2014) mengartikan etos dalam kaitannya dengan dunia kerja sebagai paradigma yang memuat semangat mulia, nilai-nilai luhur, dan moralitas unggul yang mewujud menjadi seperangkat perilaku kerja positif, seperti bekerja benar dan jujur, bekerja tulis dan ikhlas, bekerja hemat dan cermat, bekerja nirsalah dan nirboros.

Jadi, etos kerja tidak lain adalah sebuah sikap mental atau cara diri dalam memandang, mempersepsi, menghayati, dan menghargai sebuah nilai kerja. Etos kerja akan mempengaruhi semangat, kualitas dan produktifitas kerja. Etos kerja juga akan membentuk semangat transformatif, sebuah semangat yang selalu berusaha mengubah keadaan menuju kualitas yang lebih baik atau sebuah semangat dan sikap mental yang berpandangan bahwa kehidupan hari ini harus lebih baik dari hari kemarin, dan hari esok harus lebih baik dari hari ini.

Dalam kaitannya dengan program revolusi mental yang tengah digaungkan oleh rezim yang berkuasa saat ini revolusi etos kerja harus mendapat perhatian yang serius, terutama di kalangan korporasi dan birokrasi, pendidikan dan kesehatan, hukum dan politik, industri dan ekonomi, dan sebagainya. Hal ini adalah karena bangsa Indonesia, terutama pegawai umumnya sebagaimana dikatakan oleh Koentjaraningrat masih bermental feodal, mentalitas yang mengagungkan kekuasaan dan pangkat tinggi namun tidak mau bekerja keras. Mengutip pendapat J.F. Guyot, Koentrajaraningrat melukiskan beberapa karakteristik mentalitas pegawai yang negatif, yaitu bersikap tak berani mengambil resiko, tidak dinamis, tidak kreatif, tidak inovatif, gemar akan konformitas dan keseragaman, dan suka mempertahankan status quo.

Citra negatif mentalitas bangsa Indonesia juga digambarkan oleh Mochtar Lubis (dalam S, Marihot Hutahayan, 2014) sebagai berikut: munafik atau hiporkrit, enggan dan segan bertanggung jawab, bersikap dan berperilaku feodal, percaya tahyul, artistik dan lemah watak. Bahkan Abdurrahman Wahid (1981) lebih keras lagi menilai manusia Indonesia dewasa ini sebagai bangsa yang malas, bersikap pasif di hadapan tantangan yang dibawa proses modernisasi dan paling jauh tidak mampu melakukan sesuatu yang berarti atas prakarsa sendiri.

Jansen Sinamo (2011) merangkum delapan budaya kerja bangsa Indonesia yang disebutnya sebagai budaya kerja edan, yaitu:

1). Ketimbang bekerja tulus penuh rasa syukur, banyak orang lebih suka bekerja penuh keengganan karena berpendapat "gaji saya kecil sekali";

2). Ketimbang bekerja benar penuh tanggung jawab, banyak orang lebih suka bekerja demi uang semata dan menghalalkan segala cara dengan semboyan "sетua urusan memerlukan uang tunai".

3). Ketimbang bekerja tuntas penuh integritas, banyak orang lebih suka mencela rekannya yang jujur sebagai orang bodoh seraya menganjurkan agar "bekerja pintar-pintar agar selamat".

4). Ketimbang bekerja keras penuh semangat, banyak orang lebih suka bekerja santai saja dengan prinsip "takkan lari gunung dikejar".

5). Ketimbang bekerja serius penuh kecintaan, banyak orang lebih suka ala kadarnya dengan rutinitas penuh ke- 
bosanan yang di akhir minggu berseru gembira "thank God, It's Friday".

6). Ketimbang bekerja cerdas penuh kreativitas, banyak orang lebih suka bekerja seenak perut dengan berkata "kita bukan pemilik perusahaan dan negara ini".

7). Ketimbang bekerja tekun penuh keunggulan, banyak orang lebih suka bekerja sesuka hatinya dengan sikap "peduli amat, emangnya gue pikirin".

8). Ketimbang bekerja paripurna penuh kerendahan hati, banyak orang lebih suka bekerja nirpeduli dengan sikap "lho, mau apa lagi; begini sudah bagus".

Pegawai pemerintah, baik pegawai di instansi-instansi pemerintahan, tenaga kesehatan, guru-guru, dosen-dosen, kejaksaan, kepolisian, dan seterusnya.

Fenomena memprihatinkan dari etos kerja manusia Indonesia sebagaimana digambarkan oleh pakar di atas dialami hampir semua instansi pemerintahan dan swasta, termasuk di lembaga pendidikan. Tidak banyak guru atau dosen yang menjalani pekerjaannya dengan penuh rasa syukur, karena telah mendapatkan kesempatan kerja yang bagus, status kepegawaian yang permanen, gaji dan tunjangan sertifikasi yang jelas setiap bulannya. Sementara ribuan orang lainnya masih menganggur, tidak memiliki pekerjaan yang jelas, masih sibuk mencari lowong pekerjaan ke sana ke mari, masih mengkhawatirkan masa depannya. Bukankah suatu bentuk kekufuran atas nikmat Allah karena telah diberi pekerjaan yang jelas kalau kita tidak menjalani pekerjaan tersebut dengan penuh keikhlasan, kecintaan, penuh semangat dan totalitas? Bukankah suatu bentuk kekufuran atas status pekerjaan yang dimiliki kita jalani dengan penuh kemalasan, menghemat tenaga, sekedar ceklok absen kemudian pulang dan datang terlambat?
Etos kerja yang buruk sebagaimana digambarkan di atas menurut Jansen Sinamo (2014) akan membuat kita selalu galau dan risau, tak pernah merasa cukup, tak pernah merasa sejahtera dan damai dalam hidup. Lebih luas lagi sikap mental demikian sering tampil sebagai protes, demontrasi, anarki, korupsi, penjarahan, perkosaan, pelecehan, intolerasi dan pertikaian di tempat kerja. Karena itu tambah Jansen, kita perlu bertobat, berbalik arah, berubah 180 derajat, secara cepat (melakukan revolusi mental), agar kita semua kembali menjadi waras dan tak edan (sakit) lagi. Lebih jauh Jansen Sinamo mengajukan delapan butir bentuk revolusi mental di ruang kerja yang perlu segera diwujudkan oleh manusia Indonesia saat ini, yaitu:

1. Dari budaya kerja yang penuh keengganan, berubah menjadi bekerja penuh rahmat dan kebersyukuran.

2. Dari bekerja demi uang dan jabatan semata, berubah menjadi bekerja penuh amanah dan tanggung jawab.

3. Dari bekerja dengan prinsip pintarpintar asal selamat, berubah menjadi bekerja penuh keterpanggilan dan integritas.

4. Dari bekerja santai aja; tak lari gunung dikejar, berubah menjadi bekerja penuh aktualisasi diri dan semangat.

5. Dari bekerja sekedarnya penuh kebosanan, berubah menjadi bekerja yang penuh ibadah dan kecintaan.

6. Dari bekerja seenak perutnya, berubah menjadi bekerja penuh seni dan kreativitas cerdas.

7. Dari bekerja suka-suka, emangnya gue pikirin, berubah menjadi bekerja penuh kehormatan dan keunggulan mutu.

8. Dari bekerja arogan dan bergaya bos, berubah menjadi bekerja penuh pelayanan dan kerendahan hati. 


\section{PENUTUP}

Dari uraian di atas dapat diambil sebuah kesimpulan bahwa untuk dapat bangkit menjadi bangsa yang maju dan segera keluar dari berbagai krisis kehidupan yang dialami oleh bangsa ini, salah satunya adalah dengan melakukan revolusi mental dalam bidang pekerjaan atau melakukan revolusi etos kerja. Dengan melakukan revolusi etos kerja, berarti kita harus kembali menyadari eksistensi kita sebagai animal laborans (binatang yang bekerja), yang secara terus-menerus mencurahkan tenaga dan pikirannya untuk mempertahankan keberlangsungan hidupnya. Atau meminjam terminologinya Ricoeur, manusia pada dasarnya adalah suatu usaha (kerja) untuk menyempurnakan hidupnya (effort pour exister).

Dengan demikian, pekerjaan harus terintegrasi ke dalam penghayatan hidup

\section{DAFTAR RUJUKAN}

Abdul Mujib dan Jusuf Mudzakir, 2001. Nuansa-nuansa Psikologi Islam, Jakarta: Rajawali Press.

Abdurrahman Wahid, "Nilai-nilai Indonesia Apakah Keberadaan-nya kini?", Prisma, No. 11, November 1981

Anthony Reid, "Revolusi Sosial: Revolusi Nasional", Prisma, No. 8, Agustus 1981

Karlina Rohima Supelli, "Memahami Arti Revolusi Mental, http://www.sesawi.net/2014/06/16/, diakses 5 April 2015

Desmita, "Konflik Komunal dan Multikulturalisme: Memahami Situasi Konflik dalam Perspektif Psikologi Lintas Budaya, Ta'dib, Vol.VII, No. 1, Juni 2004 sebagai kegiatan penuh makna dan tidak diisolasikan melulu sebagai sarana untuk menjamin kebutuhan-kebutuhan hidup atau sarana untuk meraup keuntungan material semata. Artinya, pekerjaan tidak terasing dari keseluruhan hidup manusia dan manusia sendiri tidak pula merasa terasing di dalamnya. Bahkan, mengutip pendapat Sayyid Hussein Nasr (1990), jika dilaksanakan secara sejalan dengan syari'ah, kerja merupakan salah satu bentuk jihad dan tak dapat dipisahkan dari signifikansi religius dan spiritual yang tercakup di dalamnya. Karena itu, amatlah merugi orang memandang kerja sebagai sarana untuk mewujudkan tujuan mendapatkan materi atau uang, sebab dalam aktivitas kerja yang kerja yang dilakukannya terkandung makna yang lebih tinggi, yaitu ibadah dan meraih keridhaan Allah.

Koentjaraningrat, "Kendala Sosial Budaya dalam Pengamalan Pancasila", dalam Kompas, 14 Januari 1991

,"Kebudayaan Nasional Indonesia", dalam Kompas, 15 Januari 1991

"Jiwa Feodal, Mentalitas Pegawai, dan Disiplin Nasional", dalam Kompas, 16 Januari 1991.

M. Dawam Rahardjo, "Ruh", Ulumul Qur'an, No. 5 \& 6 Vol. V, 1994

M. Quraish Shihab, Wawasan Al-Qur'an, Bandung: Mizan, 1996.

Harun Nasution, Islam Rasional, Bandung: Mizan, 1991.

Ruslan Abdulgani, "Melacak Jejak Revolusi Nasional”, Prisma, No. 8, Agustus 1981. 
S, Marihot Hutahayan, 2014. "Dari Mental Lele ke Mental Salmon", dalam Jansen Sinamo (ed.), Revolusi Mental, dalam Institusi, Birokrasi dan Korporasi, Jakarta: Institut Darma Mahardika.

Sayyid Hussein Nasr, "Pandangan Islam tentang Etika Kerja", Ulumul Qur'an, No.5 Vol.II, 1990.

Sudjarwo, "Potret Diri Pemuda dalam Revolusi kita", Prisma, No. 8, Agustus 1981.

Wiratmo Soekito, "Etos Sosial: Suatu Refleksi”, Prisma, No. 11, Desember 1978.

Franz von Magnis, "Menuju Etos Pekerjaan yang Bagaimana?', Prisma, No. 11 Desember 1978.

Jansen Sinamo, 8 Etos Kerja Profesional, Jakarta: Institut Darma Mahardika, 2011.

-------, 2014. "Revolusi Etos Kerja", dalam Jansen Sinamo (ed.), Revolusi Mental, dalam Institusi, Birokrasi dan Korporasi, Jakarta: Institut Darma Mahardika.
Teguh Hindarto, "Revolusi Belum Selesai, Revolusi Mental", http://teguhhindarto.blogspot.com/ 2014/revolusi-belum -selesairevolusi-mental.html, diakses 10 April 2015.

, Negara Paripurna: Historisitas, Nasionalitas dan Aktualitas Pancasila, Gramedia Pustaka Utama (GPU), Jakarta, 2011.

Yudi Latif, "Keharusan Revolusi Mental", dalam Jansen Sinamo (ed.), Revolusi Mental, dalam Institusi, Birokrasi dan Korporasi, Jakarta: Institut Darma Mahardika, 2014.

Bryan A. Garner (ed.)., Black's Law Dictionary, St. Paul : West Group, 1999

Eugene Camenka, "The Concept of a Political Revolution", dalam Eugene Camenka, A World in Revolution, London: Secker, 1952.

S.N. Eisendadt, 1986. Revolusi dan Transformasi Masyarakat, terj. Chandra Johan Jakarta: CV. Rajawali. 